\title{
ENHANCING DROUGHT TOLERANCE OF TOMATO PLANTS GROWN UNDER DIFFERENT IRRIGATION REGIMES BY SOME CULTURAL PRACTICES
}

\author{
N.M. Malash, M.A. Fattahalla, Mona R. Khalil and Eman S. A. Ibrahim \\ Hort. Dept., Fac. Agric., Menoufia, Univ., Shebin El- Kom, Egypt. \\ Received: Mar. 4, 2019 \\ Accepted: Mar. 7, 2019
}

ABSTRACT: Water scarcely is a common problem especially in arid and semi-arid areas of the world like the Mediterranean region. Therefore, enormous efforts directed to improve the adaptation of plants to use less irrigation water by increasing their tolerant and resistant to water deficit by different means. In this study, tomato plants cv. "Alisa" were irrigated with three different amounts of water i.e. optimum amount which was the amount of water that added to raise soil field capacity (FC) from $70 \%$ (as re-irrigated tomato when FC drop to $70 \%$ is considered the most suitable irrigation regime) to $100 \%$ (T1), 66\% (T2) and 33\% (T3) of optimum water amount. Also, three different drought adaptable treatments were applied to tomato plants, i.e. drought pretreatment of seedlings (seedling priming), spraying plants with a reflecting antitranspirant (a suspension of calcium carbonate at concentration of $6 \%$ ) or infected plants with arbuscular mycorrizal fungus, as well as control which was not treat with any of adaptable treatment. Decreasing amount of irrigation water applied decreased gradually relative water content (RWC), No of fruits/ plant, average fruit weight and early and total yields, than those of well-watered plants (T1). The reduction in total yield was mainly due to the reduction of both fruit weight and fruit number. However, water deficit treatments (T2 \& T3) enhanced water use efficiency (WUE) and improved fruit quality i.e. increased vit. C, TSS, titratable acidity, and lycopene contents and fruit firmness in ripe fruits. The increase in fruit quality traits by water stress could be interpreted on the base that plants grown under such conditions react by stimulate the secondary metabolism which increasing plant defense, the secondary metabolites involved sugars, organic acids, vitamins, carotenoids and etc. All adaptable treatments used, often alleviated (even partly) the detrimental effects of water deficit treated plants (T2\&T3) as they promoted plant productivity of both well watered and water stressed plants than those of untreated (control) plants. The increase in total yield resulted from using adaptable treatments was mainly due to the increase in average fruit weight, and to lesser extent fruit number. Adaptable treatments also enhanced plant water relation (RWC \&WUE) compared to those of untreated control, but they considerably reduced fruit quality traits. In most cases, spraying plants with the antitranspirant material gave the highest values of yield and its components particularly when combined with well watered treatment $\left(T_{1}\right)$ and moderate water stress treatment (T2) but not with severe water stress treatment (T3). Using mycorrizal inoculation treatment gave the highest values of average fruit weight, also it gave the second highest values of plant water relations and productivity characters alternately with drought pretreatment. In addition, mycorrizal treatment gave the highest total yield when combined with lowest water supply (T3) than those obtained by other two adaptable treatments.

Key words: Tomato, water stress, mycorrhizal fungus, antitranspirant, drought pretreatment, yield, fruit quality. 


\section{INTRODUCTION}

Tomato is one of the most nutritionally and economically important crops in Egypt and around the world. Water scarcely is a common problem especially in arid and semi-arid areas of the world like the Mediterranean region. The Egyptian people (about 100 million) already face water shortage, and the shortages of water are predicted to become severe even sooner.

Drought is one of the major limitations to food production worldwide, and limited water resources affect the development of sustainable agriculture. Water stress is a menace for plants and prevents them from reaching their full genetic potential and limit the crop productivity. Reduction of plant growth is the most typical symptom of drought stress (Sairam and Srivastava, 2001). Both cell division and cell enlargement are more affected under drought owing to impaired enzyme activities, loss of turgor, and decreased energy supply (Kiani et al., 2007, Farooq et al., 2009a and Taiz and Zeiger, 2010). In addition Samuel and Paliwal (1994) reported that photosynthetic rate and stomatal conductance decreased by $50 \%$ as a result of water stress. Relative water contents (RWC), leaf water potential, osmotic potential, pressure potential, and transpiration rate are the major attributes of plant water relations (Kirkham, 2005), which are significantly affected under water deficit owing to decrease water supply. Also, Chen et al. (2013) found that water use efficiency (WUE) was significantly increased by application of $1 / 3$ or $2 / 3$ of full irrigation water amount.

Moisture stress affected tomato crop yield by reducing the number of flowers, fruit set and fruit enlargement and hence fruit number and weight (Yoon et al., 1989 \& Rao and Padma 1991). However, water shortage reduced tomato yield, fruit quality improved under certain degree of water deficit. Mitchell and Shennan (1991) found that deficit irrigation reduced tomato fresh fruit yield, but increased fruit soluble solids level and led to higher concentrations of hexoses, citric acid, and higher fruit acid concentrations. Nahar and Gretzmacher (2002) and Toor et al., (2006) reported that water stress increased sugars and acids contents such as ascorbic acid of tomato fruits. Similarly, fruit contents of total soluble solids (TSS) reducing sugars (RS), organic acid (OA) and vit.C as well as fruit firmness and color index were significantly increased by application of $1 / 3$ or $2 / 3$ of full irrigation water amount particularly at flowering and fruit development and maturation stage (Chen et al., 2013). Moreover, Matsuzoe et al. (1998) reported that under soil water stress total carotene of fully ripe fruits and the amount of lycopene were increased under water stress.

The challenge of irrigated agriculture in our time is how to produce more crops from limited water supply. One way of tackling this challenge is adoption of practices that improve drought tolerance at field scale. Using some cultural practices that enhance drought tolerance, appear to be very promising in a achieving this goal. Therefore, enormous efforts directed to improve the adaptation of plants to use less irrigation water by increasing their tolerant and resistant to water deficit by different means.

It was reported that mycorrizal inoculation improved water and nutrients uptake and status in plants partly because of the large surface area of fungal hyphae, which are much longer and finer than plant root hairs, and partly because such fungi can mobilize soil minerals unavailable to the plant's roots (Selosse et al., 2006). Stomatal conductance, transpiration rate and leaf water potential and water-use efficiency 
are often higher in mycorrhizal (M) plants than non mycorrhizal plants under drought conditions due to a higher water uptake (Augé et al., 1987, Subramanian et al., 1995, Duan et al., 1996, and Al-Karaki (1998). Consequently, such favorable effects of Mycorrhiza on enhancing nutrient uptake and water status in inoculation plants could result in improving growth, yield and quality of the products, (Edathil et al., 1996, Courtecuisse, 1999 and Smith et al., 2011).

Drought pre- treatment of seedlings at particular stage was found to ameliorates the adaptation of adult plants to stress conditions. In this respect Gonzalez Fernandez (1996) observed that tomato plants which had previously been subjected to a drought stress pretreatments were able to grow better than non - pretreated plants after 21 days under salt treatment. Also, it has been observed that adaptation of pretreated plants was maintained throughout the growth cycle (Cuartero et al., 2006 and Cayuela et al., 2007). Adaption to water deficit brings about changes in the metabolic processes and perhaps in the structure of the cell that allows the cell to continue metabolism at low water potential (Ingram and Bartels, 1996).

Also, using antitranspiration materials as foliar application can reduce the permeability of leaf surface to water vapor or movement; these processes can increase drought tolerance of plants. Most of antitranspirants have been observed to reduce transpiration to various degrees, if such materials suppressed transpiration without serious injury to the treated plants, or reduce photosynthesis it could be of considerable practical value. It was reported that there are three types of antitranspirants i.e., metabolic, film forming and reflecting materials. The later materials were mentioned to be inexpensive compared with those of film forming and not toxic unlike some metabolic antitranspirants (Patil and De, 1976). Abou- khaled et al. (1970) showed that the role of reflecting materials in reducing transpiration was mainly depend on decreasing absorption of radiant energy and thereby reduce leaf temperature of $\left(3-4 C^{5}\right)$ which in turn diminished transpiration rate of $30 \%$. Also, Malash and Gawish (1990) reported that white wash (a suspension of calcium carbonate) as reflecting antitranspirant enhanced growth, yield and leaf moisture content of cowpea plants grown under saline or non- saline conditions. Similarly, Farouk and Ramadan (2012) found that foliar-applied of chitosan which is a reflectant antitranspirant counteracted the harmful effect of water stress, as it increased yield and its quality of cowpea under stressed and non-stressed conditions compared with untreated plants.

Thus the aim of this work is to study the effect of some adaptable treatments such as antitranspirant application, mycorrhizal inoculation and seedling drought pre-treatment (priming) in alleviation water stress (by using lesser amount of irrigation water than optimum) on productivity of tomato plants.

\section{MATERIALS AND METHODS}

This experiment was carried out in three successive early summer seasons from 2014 to 2016 at the Agricultural Experimental Farm, Faculty of Agriculture, Menoufia University in Shibin El-Kom, Egypt. In this study, tomato plants were subjected to different irrigation regimes i.e. irrigated with three different amounts of water. Also, three different drought adaptable treatments were applied to tomato plants i.e. drought pretreatment of seedlings, spraying plants with reflectant antitranspirant or infected with an arbuscular mycorrhizal fungus to study their effects on 
productivity of tomato plants particularly when deficit irrigation treatments were applied. The soil was clay loam in texture, with $E C=0.42 \mathrm{dS} / \mathrm{m}$, organic matter $=1.37 \%$ and water field capacity = $38.8 \%$.

Seeds of tomato (Solanum lycopersicum) cv. Alisa were sown in speeding trays on $1^{\text {st }}$ of January in the first and on $5^{\text {th }}$ of January in the second and third seasons. The seedlings were transplanted 50-60 days afterwards.

Transplants were set on north side of rows $100 \mathrm{~cm}$. apart and $3 \mathrm{~m}$ long with 50 $\mathrm{cm}$ between transplants. Each plot consisted of 3 rows. The plot area was 6 $\mathrm{m}^{2}$ and the distance between the two adjacent plots was not less than $1.5 \mathrm{~m}$ to reduce treatment over lapping as possible.

To obtain good plant establishment, all plots were irrigated as normal i.e. as occur in tomato production fields in the area, in the first two irrigations. The $3^{\text {rd }}$ irrigation added at 20-25 days after transplanting and was considered the beginning of practicing the three different irrigation treatments.

All plots were fertilized according to the recommendations (rates and time of applications) of ministry of agriculture in old land. Other cultural practices were applied as commonly practice in tomato production field in the area.

\section{Treatments used}

Three amounts of irrigation water (irrigation regimes) were used as follows:

1. Full irrigation (T1) is the optimum amount of irrigation water for tomato (full water requirement i.e. $100 \%$ of optimum irrigation water amount) which is the amount of water added to raise water content from $70 \%$ to $100 \%$ of field capacity (FC). Many previous worker recommended that irrigation at $70-75 \%$ FC was considered the most suitable irrigation regime for tomato (Nahar and Gretzmacher, 2002, liu et al., 2009 and Nahar and Ullah, 2011)

2. Applied $2 / 3$ or (66 \%) of the optimum amount which was considered moderate water deficit (T2).

3. Applied $1 / 3$ or (33\%) of the optimum amount which was considered severe water deficit (T3).

Soil moisture was determined gravimetrically between irrigations. Soil samples were taken every 2 days between successive irrigations from each treatment by using an iron tube with a sharp circular cutting edge named (regulator Auger). The samples were immediately transferred in tightly closed aluminum cans to the laboratory and weighed, then soil samples were dried in an oven at $105^{\circ} \mathrm{C}$ till constant weight.

Soil moisture percentage was calculated according the following equation:

$\%$ S.M. = $\frac{\text { loss of weight bydrying }}{\text { weight of oven dry soil }} \times 100$
$\%$ S.M. = Soil moisture percentage.

Soil moisture measurements were used to determine the date of irrigation.

During the entire period of the experiment, the depletion of water for each plot was carefully measured in all treatments (as mentioned above). Irrigation water was applied when soil moisture reached $70 \%$ of it's field capacity, only in plots devoted to treatment of optimum amount of irrigation water (T1), to raise moisture of the soil to $100 \%$ FC. Other deficit irrigation water treatments (66 and $33 \%$ of optimum amount of irrigation water) were irrigated at the same time with T1 but received only $66 \%$ and or $33 \%$ of the amount of water applied to T1 respectively. The desired quantity of water needed to $\mathrm{T} 1$ was calculated using the following formula: (Aron, 1972). 
Where:

$$
\mathbf{Q}=\frac{(F \cdot C-S \cdot M \cdot D) \mathrm{BdxDxR}}{100}
$$

$Q=$ the quantity of water in cubic meter.

F.C = field capacity of the experimental field.

$S . M . I=$ the percentage of soil moisture before irrigation.

$\mathrm{Bd}=$ Bulk density of the soil in $\mathrm{gm} / \mathrm{cm}^{3}$. $D=$ Soil depth required to be irrigated.

$\mathbf{R}=$ Area that would be irrigated.

Tap water was the source of the irrigation water, which was delivered to each experimental unit through rubber tube. In addition water flow and water amount were controlled by using normal water counter.

\section{Drought adaptable treatments (sub treatments) were:}

1) Drought pretreatments of seedlings: seedlings were subjected to drought (by withholding irrigation water) at $5^{\text {th }}$ leaf stage for the maximum period that permitted subsequent recovery of at least $90 \%$ of the pretreated plants (Cuartero et al., 2006 and Malash and Khatab, 2008). Then the seedlings were irrigated and after recovery of seedling they were transplanted to the field. This process was carried out while seedlings were growing in the speeding trays.

2) Tomato plants were sprayed with water suspension of calcium carbonate at concentration of $6 \%$, it used as a reflecting antitranspiration (Malash and Gawish, 1990). The reflected antitranspiration was applied four times with 10 days intervals beginning at 27days after transplanting.

3) Tomato plants were infected at 5 days after transplanting by arbuscular mycorrizal fungus (Glamous sp.) endogenous mycorrizal. It was added to the soil in a liquid case beside plant roots with equal amount $\left(20 \mathrm{~cm}^{3} / p l a n t\right.$ which consist of 50 spores around root area ). Mycorrhizal was provided from Ain Shams University, Faculty of Agriculture, Microbial Inoculants Unit.

4) Control i.e. no further adaptable treatment was applied.

In all cases seedlings were transplanted at the same time in the field.

The design of the experiment was split plot design with 3 replications. Water amounts treatments and drought adaptable treatments were assigned respectively to main and sub plots.

\section{Data recorded:}

Although this experiment was carried out for three years i.e. 2014, 2015 and 2016, only data of the 2015 and 2016 were presented. Trail carried out in 2014 used as preliminary study.

\section{Plant water relations:}

1- Relative Water Content (RWC): The $5^{\text {th }}$ leaf from the plant top were taken from three randomly selected plants from each treatment at 62 day after transplanting. The RWC was calculated by the following equation as described by Barrs and Weatherly (1962).

$$
\mathrm{RWC}=\frac{F W-D w}{T w-D w} \times 100
$$

Where:

$F W=$ fresh weight of leaf discs.

DW =dry weight of discs (at $70^{\circ} \mathrm{C}$ till constant weight).

TW=full-turgor weight i.e., turgor weight was determined by floated 10 leaf discs $(1 \mathrm{~cm}$ in diameter) from each treatment on distilled water in petri dishes under laboratory conditions. The discs left in the water for sufficient time and then weighed every 15 minutes they get out of the water after showing constant weight, discs were blotted before weighing. 
RWC can be successfully used to identify drought- resistant crops. It was also called relative turgidity and is perhaps the most widely accepted method of expressing the quantity of water in plant tissue (Boyer, 1969).

2- Water use efficiency (WUE): At the end of the growing season total amount of water applied to each treatment (in $\mathrm{m}^{3}$ ) and total yield $(\mathrm{Kg})$ obtained from the same treatment were used to calculate WUE according to the following formula.

$$
\text { WUE }=\frac{\text { Vield }(\mathrm{kg})}{\text { Water } \text { applied }\left(\mathrm{m}^{3}\right)}
$$

\section{Yield and its components:}

Ripe fruits were harvested every 3-4 days during the harvesting season, fruit weight and numbers were determined simultaneously for each harvesting. Yield and it's component were determined as follows:

a) Early yield: was the fruit yield of the first three harvests.

b) Total yield: was the weight of all harvested fruits throughout the entire harvesting season.

c) Number of fruits per plant throughout the harvesting season.

d) Average fruit weight: was determined by dividing the weight of fruits by their total number.

\section{Fruit quality:}

Fruit quality and chemical contents (vit.C, TSS, titratable acidity, firmness and lycopene) were determined in fruit samples taken randomly from the $2^{\text {nd }}, 4^{\text {th }}$ and $6^{\text {th }}$ harvestings and average values were only presented:

a) Fruit firmness was determined by the fruit and vegetable tester (John Chatillon \& Sons Ine., Kew Gardens, New York, U.S.A) using gauge 516500 MRPFR (puncture test). Each fruit was tested at 3 positions: near the blossom end, at the shoulder and in the middle of the fruit. Then, average value was calculated for each fruit.

b) Ascorbic acid content in tomato juice: (Vitamin C) the determination was carried out using 2, 6, dichlorophenol indophenol dye and oxalic acid as extractor as described in A.O.A.C., 1965.

c) Lycopene pigment content in tomato fruits: were determined by using method described in A.O.A.C., 2003. Lycopene was measured with a spectrometer model (CT- 2200 spectrophotometer (Med Line Scientific Limited).

d) Total soluble solids (TSS) content: were measured using an abbẻ hand Refractmeter.

e) Titrable acidity: The acidity in fruit juice was assayed as citric acid by the titration with $0.7 \mathrm{~N}$ sodium hydroxide after adding a few drops of phenolphthaline as an indicator (A.O.A.C, 1975).

\section{Data statisticall analysis:}

The data of two seasons were statistically analyzed using the CoStat package program, version 6.311 (Cohort software, USA). The differences among the means of treatments were tested using the least significant differences (L.S.D) at 0.05 level of probability according to the method described by Snedecor and Cochran (1980).

\section{RESULTS AND DISCUSSION}

1- Effect on plant water relations

1.1. Effect on relative water content (RWC)

RWC is perhaps the most widely accepted method of expressing the quantity of water in plant tissue. As amount of irrigation water decreased RWC also gradually and significantly decreased in tomato leaves in both 
seasons (Table 1). The reduction in RWC, (average of the two seasons) compare to that of well water treatment (T1) were 25 and $53 \%$ when plants irrigated with $66 \%$ (T2) and $33 \%$ (T3) of optimum amount of water respectively (Table 1 ). Thus, these findings are in agreement with those reported by Chengkun et al. (1996), Subramanian et al. (2006) and Ozkur et al. (2009) who found that drought lowered RWC in tomato plants.

Table 1 also shows that the three adaptable treatments (antitranspirant sprays, drought pretreatment and mycorrizal inoculation) all enhanced RWC in tomato leaves, comparable to those of untreated control, in both seasons. Mycorrizal inoculation gave significantly the highest RWC in leaves in the first season, but in the second one differences between RWC values obtained by using any of the three adaptable treatments were not significant. These results confirmed previous reports regarding the favourable effect of mycorrizal on improving water status in plants (Subramanian et al., 1995) as the fungal mycelium has higher absorptive capacity (because of its large surface area) for water and other minerals.

Also, using antitransparent sprays reduced transpiration and enhanced water status in plants. Drought pretreatment also improved water content in tomato plants, but by encourage solutes accumulation which leading to conserve water in plants (Villar-Salvador et al., 2004).

According to the data given in Table 1, the highest values of RWC in tomato leaves were in plants irrigated with the optimum amount of irrigation water, whatever was the adaptable treatment used, this result was true in both seasons. In addition, it is obvious that foliar spraying of plants with antitransparent produced the highest RWC in leaves of plants particularly when irrigated with the optimum amount of water. Moreover, RWC in leaves of plants that received the combination between antitransparent application and $66 \%$ of optimum amount of irrigation water (T2) also gave the highest value of R.W.C among water deficit treatments whatever were adaptable treatments.

\subsection{Effect on water use efficiency (WUE) \\ WUE significantly increased as} amount of irrigation water decreased (Table 1), in both seasons. This result confirmed with the results obtained by Liu and Chen (2002), Abbate et al. (2004), Zhao et al. (2006) and Subramanian et al. (2006) who detected higher WUE in wheat and tomato under drought than well watered control, mainly due to reduce transpiration rate under drought conditions and hence less water uptake.

WUE of plants received any of the adaptable treatments were significantly higher than WUE obtained by control plants (Table 1). Values of WUE obtained by either of adaptable treatments were not significantly differ among them in the 2015 season. In 2016 season, using drought pretreatment gave significantly the highest WUE among adaptable treatments, while WUE values obtained as a result of antitranspirant application and mycorrizal inoculation were not significantly differ (Table 1).

These findings are in accordance with those of Moftah and Al- humide (2005) who mentioned that reflectant antitranspirant increased WUE in potato plants grown under water stress. Also, Al-karki and Clark (1999) and Farahani et al. (2008) showed that WUE was increased with application of mycorriza under drought conditions. In all cases the adaptable treatments increased RWC (as previously mentioned) in plant tissues which in turn enhanced physiological process and improve metabolic activity 


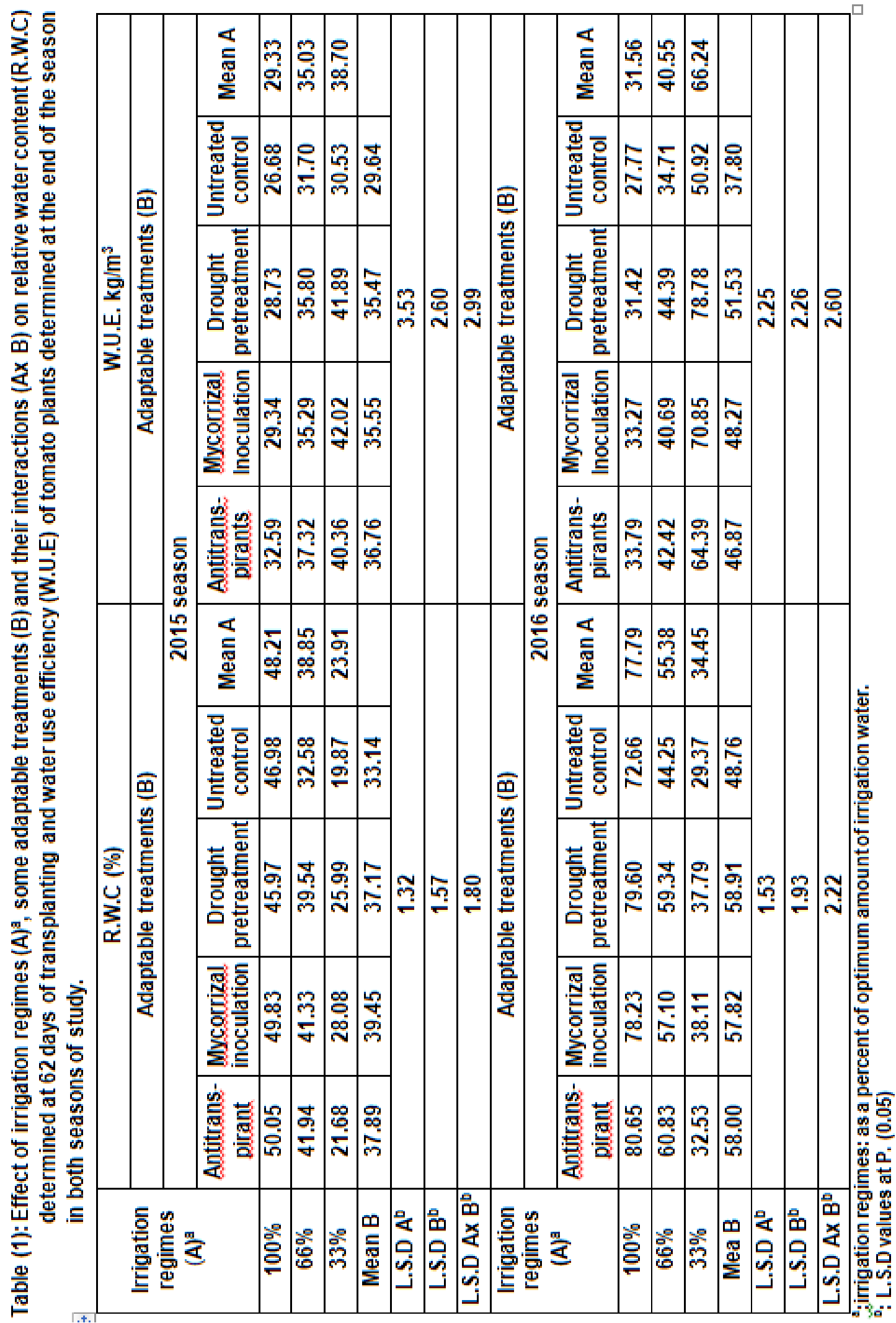


and hence gain more yield without consume more water. In other words, the higher values of WUE obtained when the lowest amount of water applied was attributed to that the reduction in yield was not sever as much as the reduction in water applied.

\section{Effect on total yield and its components}

2.1. Effect on total fruit number / plant

As expected decreasing amount of irrigation water decreased gradually and significantly number of fruit/ plant (Table 2). Irrigation with the lowest amount of water (T3) considerably reduced fruit number /plant. Similar results were obtained by Vieria et al. (1991), Beverly and Latimer (1995), Pulupol et al. (1996), Rahman et al. (1998) and Krinka et al. (2001) regarding the reduction of fruit number by water stress. The reduction in fruits number was attributed either to flower or fruit drop or to low fruit set brought about by water stress (Rao and Padma, 1991). Also, Roa and Bhatt (1992) reported that in tomato plants continuously water stressed after seedling establishment, a fruit drop of 20$25 \%$ may occur.

Results presented in Table 2 show that all adaptable treatments used in this study often did not significantly increase fruit number over those obtained by plants of untreated control. Spraying plant with antitranspirant only in the first season resulted in increasing fruit number significantly when compared to those of untreated control (Table 2).

Meanwhile, the differences in fruit number / plant as affected by different adaptable treatments were not significant except in one case (Table 2).

Data in Table 2 show that number of fruit/ plant was highest when the plants were irrigated with optimum amount of irrigation water whatever was the adaptable treatment used. However, the

lowest fruit number was obtained when plants irrigated with the lowest irrigation water amount regardless of adaptable treatments used. With very few exceptions it seems that adaptable treatments had a slight favourable effect on fruit number only when plants irrigated with $66 \%$ but not with those irrigated with $33 \%$ of optimum amount of irrigation water. This may suggest that the effect of severe water deficit cannot modified by such adaptable treatments.

\subsection{Effect on average fruit weight}

Decreasing irrigation water than its optimum amount reduced average fruit weight and the reduction in weight was gradually and significantly, as amount of irrigation water decreased (Table 2). The reduction percentages in fruit weight (as average of the two seasons) were $\mathbf{1 1 . 9}$ and $27.5 \%$ with 66 and $33 \%$ of optimum irrigation water amount, respectively. These results agreed with former reports regarding the reduction of fruit weight by water stress (Yoon et al., 1989, Beverly and Latimer, 1995 and Rahman et al., 1998). The reason of the reduction in fruit weight as a result of water stress may be return to the reduction in fruit enlargement due to low water content in fruits, (Yoon et al., 1989).

Unlike fruit number/ plant using
adaptable treatments significantly
enhanced average fruit weight over those
of untreated control (Table 2). Meanwhile
differences in average fruit weight
produced by plants received either of the
three adaptable treatments were not
significantly differ in both seasons (Table
2). This result suggests that improving
water status in adaptable treated plants
leading to enhance fruit enlargement and
weight. Similar results was also obtain by
Beverly and Latimer (1995) who reported
that average fruit weight of drought
conditioned plants was $28 \%$ greater than
those taken from plants receiving no
conditioning.




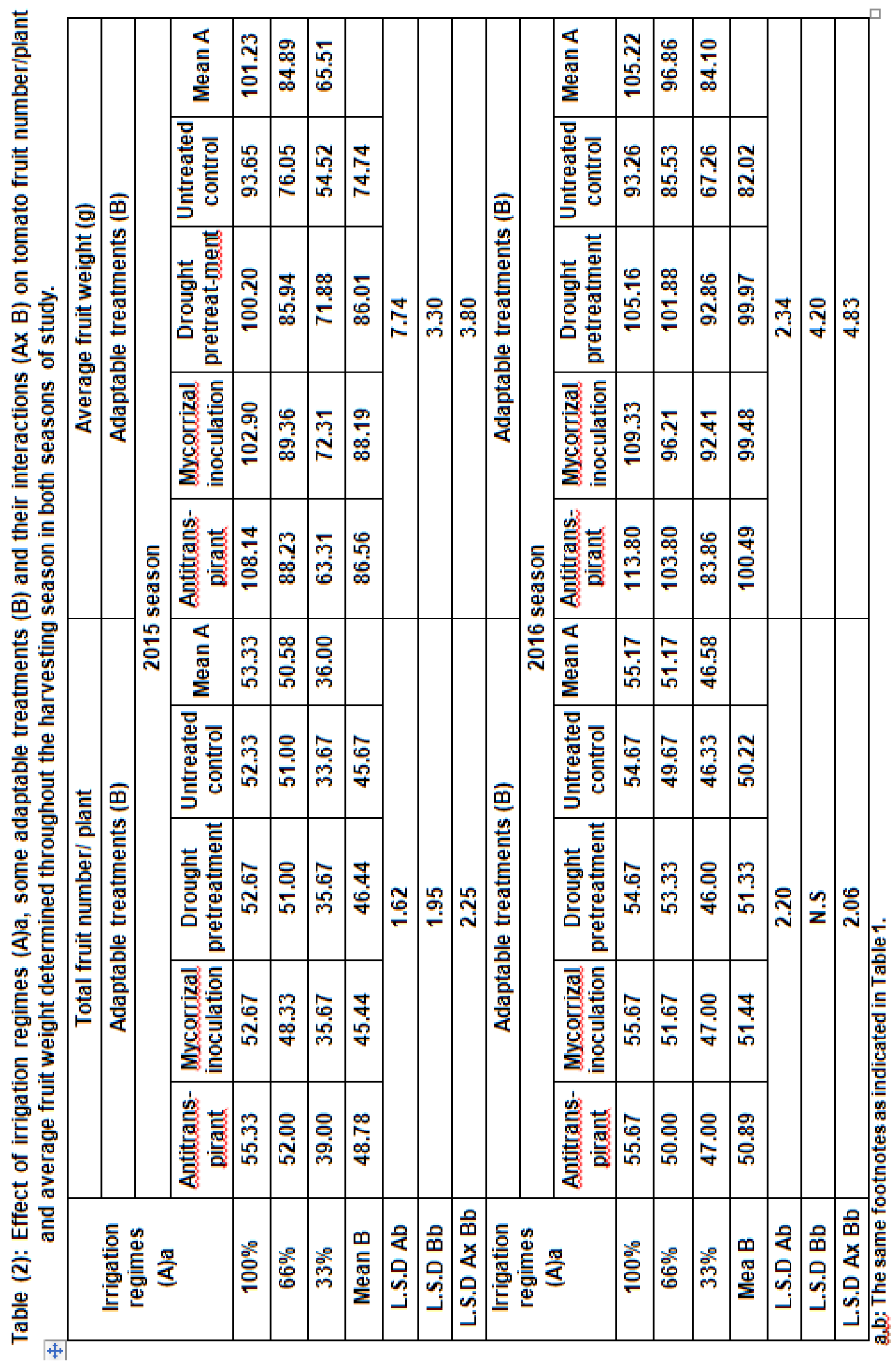


It is obvious from data presented in Table 2 that although there were no significant differences between fruit weight produced from plants treated with any of the three adaptable treatments (as average), using antitranspirant spraying resulted in increasing fruit weight significantly over other adaptable treatments only when this treatment combined with irrigation with $100 \%$ of optimum amount of irrigation water. However, when lowest amount of water (T3) added, combined with treatment of antitranspirant showed significantly lower fruit weight when compared with weight of counterpart fruits of other two adaptable treatments. The alteration in average fruit weight as affected by using antitranspirant spraying and different level of irrigation water amounts seems to be quiet related to water status in plants, as fruit weight produced, as result of this combination, almost follow their counterpart data of RWC in leaves of plants (Table 1). This observation of obtaining the lowest fruit weight and the lowest RWC value in plants treated with antitranspirant and T3 may suggest that partially stomata closing by water stress treatment $(33 \%$ of optimum irrigation water) plus the effect of antitranspirant application may brought about a large reduction in transpiration which may effect on water uptake and hence low RWC (Table 1), which predisposing to lower fruit weight.

\subsection{Effect on early yield}

According to the data given in Table 3, reducing amount of irrigation water applied from $100 \%$ to $33 \%$ of optimum amount decreased gradually and significantly early yield of tomato, in both seasons of study. The average reduction of the two seasons in early yield were respectively $18.6 \%$ and $48.2 \%$ when $66 \%$ and $33 \%$ of optimum amount of irrigation water were used compared to $100 \%$ treatment. The reduction in early yield by water stress treatments may return to the lower average fruit weight and fewer numbers of fruits produced/plant

Data in Table 3 show that early yield of plants received adaptable treatments (antitranspirant, drought hardening and mycorrizal inoculation) was significantly higher than that obtained by those untreated (control), in both seasons of study. Early yield obtained by antitransparent application was significantly higher than that obtained by other two adaptable treatments (drought hardening and Mycorrizal inoculation) only in one season (2015 season). But differences in early yield values obtained by other two adaptable treatments were not significantly differ in 2015 and between the three adaptable treatments in 2016 (Table 3).

The results in Table 3 indicated that the highest early yield was recorded for plants received $100 \%$ of optimum amount of irrigation water and sprayed by antitranspirant, the second highest early yield was obtained in plants received $100 \%$ of optimum water amount combined with mycorrizal inoculation. However, the lowest early yield was obtained by the combination between the lowest amount of T3 and control treatment. Nevertheless the second lowest early yield was recorded for the combination between antitranspirant treatment with T3.

\subsection{Effect on total yield}

Results presented in Table 3 show that total yield of tomato decreased significantly and gradually with decreasing amount of irrigation water. The reductions (as a percentage) in total yield as an average of the two seasons were $17.5 \%$ and $44.0 \%$ when $66 \%$ and $33 \%$ of optimum amount of irrigation water were applied respectively. These results agreed with former reports 


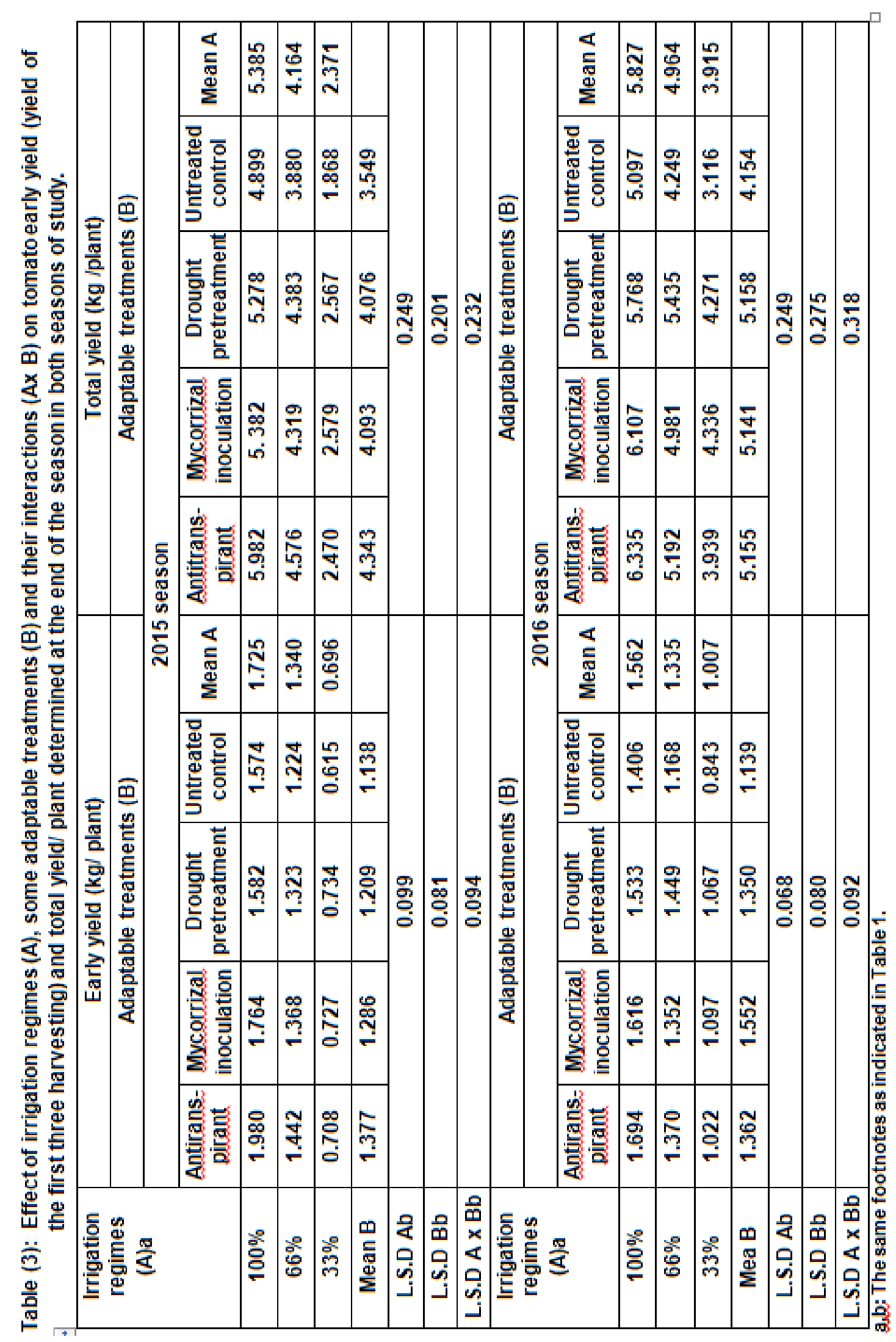


regarding the deteriorative effect of water deficit on tomato yield (Sivakumar and Srividhya, 2016, Liu and Chen, 2002, Rahman et al., 1998 and Ul et al., 1994).

The reduction in yield by water deficit was attributed to the reduction in flower formation, fruit set, fruit enlargement (Yoon et al., 1989) and fruit number and weight (Beverly and Latimer, 1995).

In this study the reduction in total yield occurred as a result of water stress was mainly attributed to the reduction in average fruit weight and to less extent number of fruits (Table 2). This result support the previous report of Panagitopoulos and Fordham (1995) who mentioned that reduction in total fruit yield of tomato mainly due to reduce fruit size.

Also, the data (Table 3) indicate that the three adaptable treatments (antitranspirant spraying, drought hardening and mycorrizal inoculation) significantly increased total yield of tomato plants over that obtained by untreated control plants. The differences between values of total yield obtained by the three adaptable treatments were not significantly differ except in one case i.e. when antitransparent material applied in 2015 in which gave significantly higher total yield than other two adaptable treatments.

The favourable effect of mycorrizal inoculation on total yield of tomato grown under water stress conditions was also found elsewhere (Auge, 2001, RuizLozano, 2003, Kaya et al., 2003 and Subramanian et al., 2006).

Data in Table 3 show that the highest and the lowest total tomato yields were obtained when antitranspirant application combined with the optimum amount of irrigation water treatment and when untreated (control) plants combined with the lowest amount of irrigation water respectively, in both seasons of study.
Also, the reduction in total yield was aggravated when the lower amount of irrigation water (T3) was applied with any of the adaptable treatments particularly with antitranspirant one (Table 3). However, using any of the adaptable treatments (only when combined with the moderate irrigation water amount i.e. $66 \%)$ gave total yield either with slight decrease (differences were significant) in 2015 season or slight increase or quite similar (differences were not significant) in 2016 season when compare to total yield obtained from plants received $100 \%$ of optimum amount of irrigation water and did not receive any of adaptable treatments (control plants). This may suggests that adaptable treatments used in this study could often alleviate moderate drought effect on tomato yield.

\section{Effect on fruit quality and chemical contents}

\subsection{Effect on vit.C}

Decreasing amount of irrigation water applied increased significantly vit.C content in tomato fruits (Table 4). However, the highest vit.C content was in fruits produced by plants received the moderate amount of irrigation water i.e. $66 \%$ of optimum irrigation water amount in both seasons. Similar results were obtained by Liu and Chen (2002), Nahar and Gretzmacher (2002), Toor et al. (2006) and Chen et al. (2013) who reported that water stress increased sugars and acids contents such as ascorbic acid of tomato fruits. The increase of vit.C content in fruits produced under water stress conditions may be due to altering environmental conditions which occur as a result of reducing vegetative growth vigor which allow fruits greatest exposure to light and relatively high temperature (McCollum, 1944, Brown, 1955 and Liptay et al., 1986) and to the effect of stress on increasing synthesis of secondary metabolites compounds and antioxidants including vit.C. 


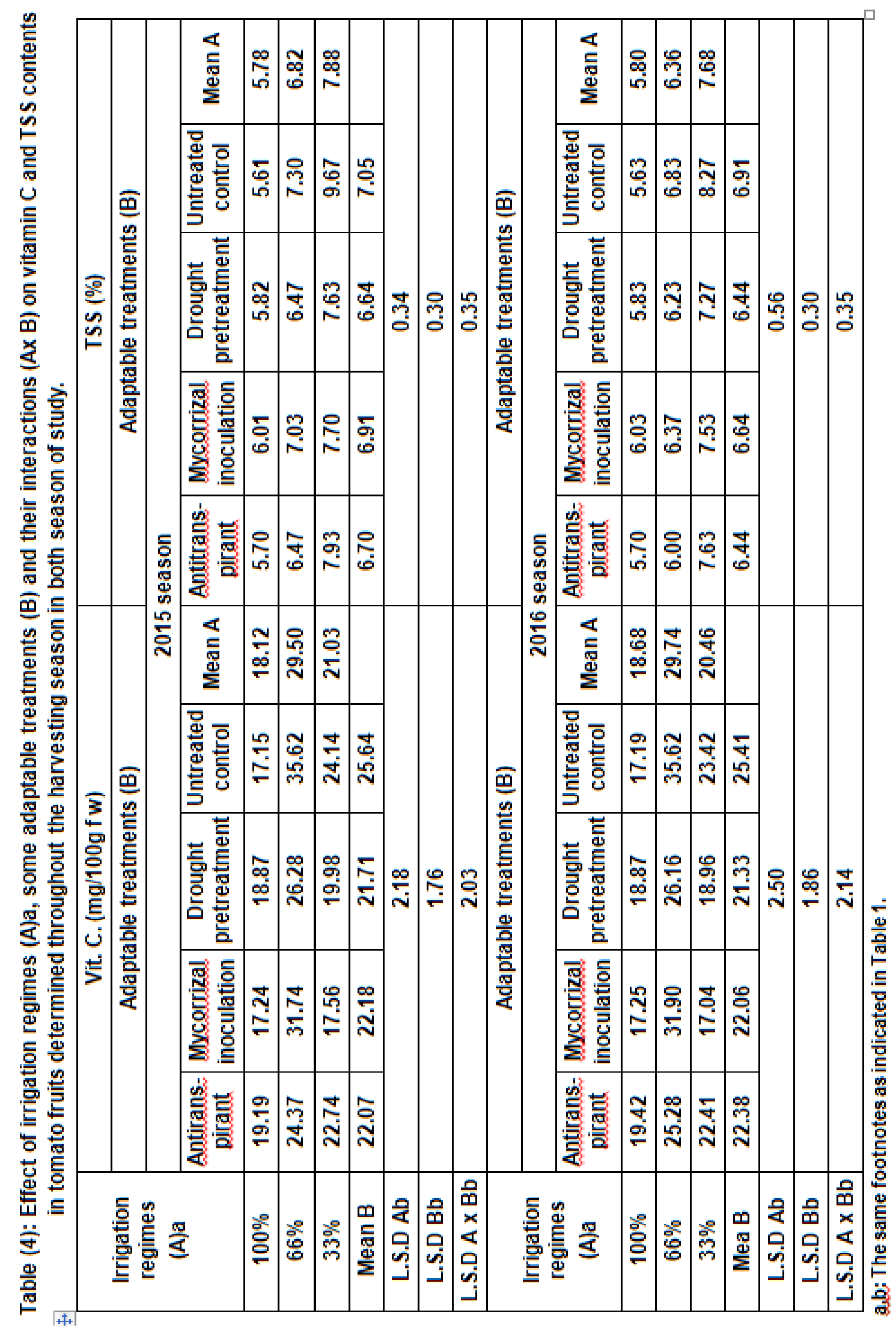


Data in Table 4 show that fruits of plants that did not receive any of three adaptable treatments (antitransparent, drought pretreatment and mycorrizal inoculation) i.e. those of untreated control had significantly higher vit.C. content than those fruits produced from plants received any of the adaptable treatments. Meanwhile, the differences in vit.C contents in fruits produced by plants treated by any of the three adaptable treatments were not significant (Table 4). These findings do not in agreement with those reported by Subramanian et al. (2006) who suggested that mycorrizal inoculated plants, produced tomato fruits that contain significantly higher quantity of ascorbic acid than un inoculated plants when both grown under drought stress conditions.

The effects of adaptable treatments which enhancing growth (which gave more shading) besides decreasing sugars and acids concentrations by improving water status of adaptable treated plants which also minimize the need to increase antioxidants compounds may be the reason of reducing vit.C. in fruits produced from plants received such treatments.

Table 4 shows that the highest vit.C. content were in the fruits produced untreated by plants with any of adaptable treatments (control) followed by fruits of plants treated by mycorrizal inoculation, both in combined with irrigation with $66 \%$ of optimum water amount in particular, in both years of study. However, the lowest vit.C. contents were observed in fruits of plants received the optimum amount of irrigation water $(100 \%)$ among those fruits produced by plants received any of adaptable treatments (Table 4).

\subsection{Effect on total soluble solids (TSS)}

As expected TSS values were higher in fruits produced from plants that received less amount of irrigation water than fruits produced from plants received optimum amount of water (Table 4). These findings are in agreement with those reported by Ito and Kuawai (1994), Panagitopoulus and Fordham (1995), Liu and Chen (2002) and Chen et al. (2013) regarding the enhancement effect of water deficit on TSS of tomato fruits. Water deficit may benefit tomato fruits quality due to the increased levels of total soluble solids (sugars, amino acids and organic acids) which are major compounds that accumulate in the fruits (Yin et al., 2010 and Nuruddin et al., 2003). In this respect sugars constitute 65 to $70 \%$ of the fruit TSS (Hosbon and Grierson, 1993). Moreover, the differences in TSS content resulting from using different water treatments may due to differences in water content of the fruits of mango (Abdel- Razik, 2012). Also, Ho and Grimbly (1990) and Mitchell et al. (1991) elicit that the increases in TSS by water stress are mainly due to the decrease in fruit water content and to a slight increase in soluble sugar accumulation.

High soluble solids increases the value of fresh fruits and improves of the quality of the fruits because it affects the flavour, taste and water content of the fruits.

Results in Table 4 show that fruits produced from untreated plants by any of the three adaptable treatments (i.e. untreated control) had significantly the highest TSS content, in both season of study. Meanwhile, TSS content in fruits that harvested from plants treated with any of the three adaptable treatments were not significantly differ among them (Table 4). These findings do not in agreement with those reported by Subramanian et al. (2006) who suggested that mycorrizal inoculated plants, produced tomato fruits that contain 
significantly higher quantity of total soluble solids than un inoculated plants when both grown under drought stress conditions. It seems that the favourable effect of the three adaptable treatment on improving water status (R W C) in plants as previously shown in Table 1 , may be the reason of reducing TSS concentration (\%) in fruits treated with such adaptable treatments, comparable to those produced by the untreated plants (control)

Results in Table 4 also indicate that the highest TSS content was in fruits of the untreated plants with any of adaptable treatments (control) and received the lower amount of water $(33 \%)$. On the other hand, the lowest TSS content was recorded in fruits produced from plants that received the optimum amount of irrigation water and did not subjected to any of those adaptable treatments in both seasons of study (Table 4).

Thus, it is obvious that water status in plants (and fruits) is the main factor affecting TSS content whatever was the adaptable treatment used. To further elucidate, water deficit enhanced sugars and organic acids assimilation, besides reduced dilution of such compounds, therefore TSS increased. Otherwise, under well water conditions sugars do not accumulate and abundant water content may reduce TSS concentration.

\subsection{Effect on titratable acidity}

The titratable acidity (TA) showed similar response to irrigation regimes as did TSS content (Tables 4 \& 5). Titratable acidity increased gradually and significantly in tomato fruits as irrigation water amount decreased, in both seasons. The increase in TA percentage, as an average of the two seasons, were 26.8 and $50 \%$ when $66 \%$ and $33 \%$ of optimum amount of irrigation water applied respectively, over those received $100 \%$ of optimum amount of irrigation water. The increase in TA content in fruits grown under water stress was also observed elsewhere (Mitchell and Shennan, 1991, Panagitopoulos and Fordham, 1995, Veit-Kohler et al., 1999, Liu and Chen, 2002, Chen et al., 2013 and Agbemafle et al., 2014).

Results presented in Table 5 show that acidity was significantly high in fruits produced from plants of untreated control i.e. did not treated with any of those adaptable treatments in both seasons of study. Meanwhile, differences in acidity content in fruits harvested from plants treated by any of the three adaptable treatments were not significant, in both seasons. This result may suggest that water regimes (amount of irrigation water) had the main effect on fruit acidity content than adaptable treatments effects.

The highest value of TA was in fruits harvested from plants irrigated with $33 \%$ of optimum amount of irrigation water in combined with the untreated control (Table 5).

\subsection{Effect on fruit firmness}

Results in Table 5 show that fruit firmness increased gradually and significantly with decreasing amount of irrigation water applied, in both seasons of study. These results agreed with former reports, which indicated that tomato fruit firmness was significantly increased by application of $1 / 3$ or $2 / 3$ of full irrigation water amount (Chen et al., 2013). Similar findings were also reported by Lopez et al. (2011) and by Abdel-Razik (2012) who indicated that water deficit increased firmness of pea pods and mango fruits, respectively. In addition some workers observed a positive link between dry matter or total soluble solids and firmness of tomato fruits (Aurand et al., 2012). However, Agbemafle et al. 
on

突

름

皆

峁 总

氜

氖

등

ติ

迮

듣

을

๘

을

亳

흘 몰

色

는

흘

옹

品

믐

몸 원

总

空

\&

莺

ญ ․ㅡㄴ

을 응

는 응

느응

넝

穹

ติ

음

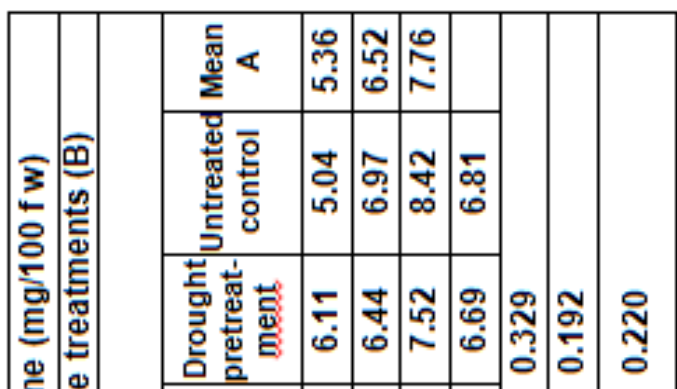

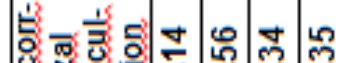

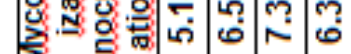

초몽

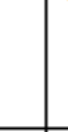

จิ

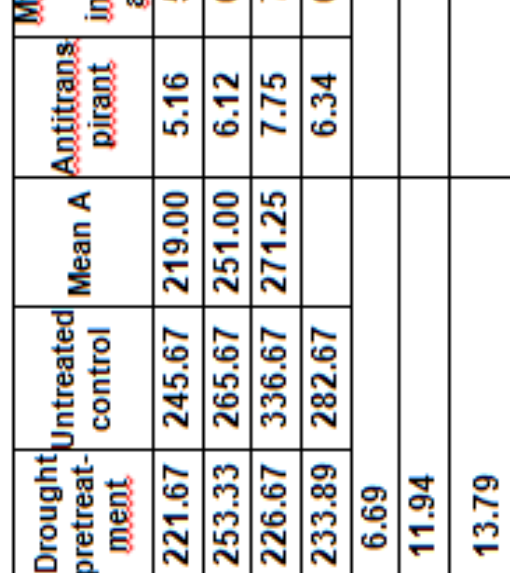

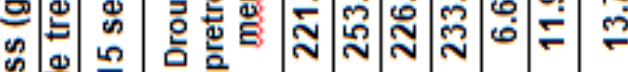

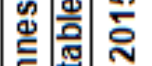

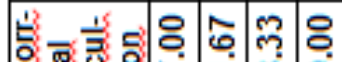

동

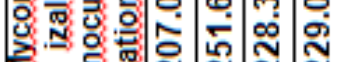

ㄱ.

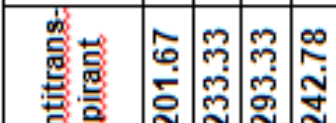

-

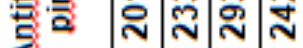

鱼 总

昰高

음

$\div$

営高

永高

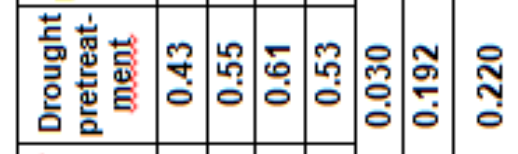

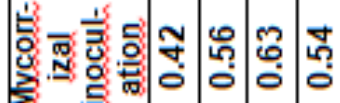

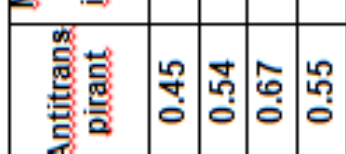

효

黄婹

을

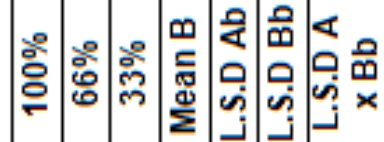

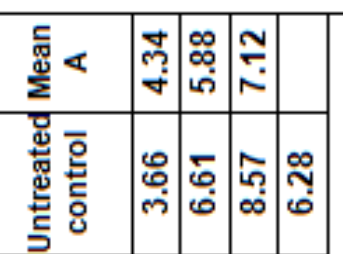

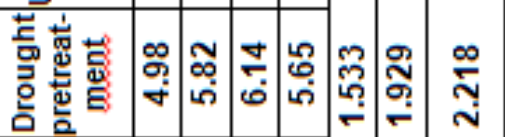

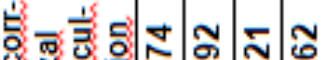

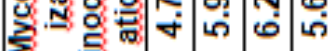

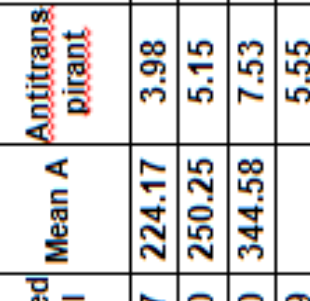

한

बू.

亏్

ก ก ก กัก

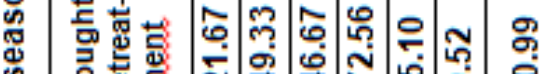

。

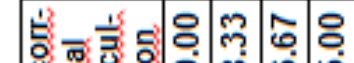

ख.

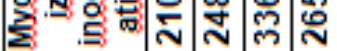

买菟

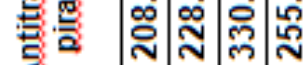

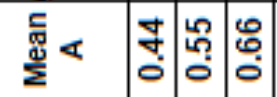

总

c: 0000

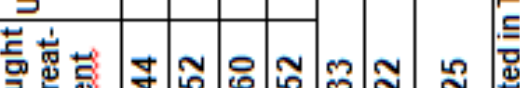

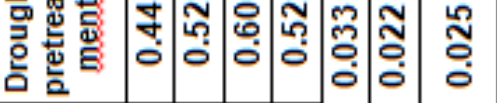

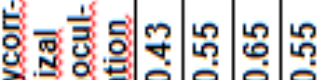

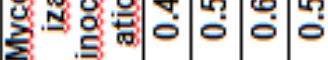

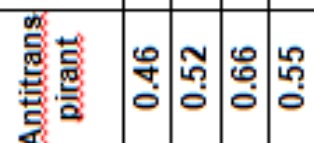

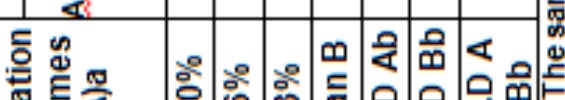

爱言㟧

트 
(2014) reported that although deficit irrigation increased tomato fruit firmness, but differences between the effects of different irrigation treatments were not significant.

Using the three adaptable treatments (antitranspirent application, drought pretreatment and mycorrizal inoculation) resulted in decreasing fruit firmness significantly compared to those produced by untreated control plants in both seasons (Table 5). The effect of adaptable treatments on tomato fruit firmness were discrepancies between the two seasons, besides differences in fruit firmness among these treatments were not significant in most cases.

The report of Aurand et al. (2012), previously mentioned above may explain, even in part, the reason of decreasing fruit firmness when plants treated with such adaptable treatments. Improving water stress in plants by using such treatments may negatively affect dry matter content in fruits and hence on fruit firmness.

Fruit firmness of plants treated with each of adaptable treatments at any amount of irrigation water used were lower than their counterparts that were not treated (Table 5). This result may suggest that adaptable treatments had no favourable effect on fruit firmness, unlike amount of irrigation water applied, but they impaired it.

\subsection{Effect on lycopene content in tomato fruit}

It is obvious from results presented in Table 5 that lycopene content in tomatoes increased as irrigation water amount decreased, and the plants that irrigated by the lowest water amount produced fruits contained the highest lycopene content, in both seasons. Thus, these findings support the previous findings of Klunklin and Savage (2017),
Sivakumar and Srividhya (2016), Giannakoula and Illias, (2013), Chen et al. (2013) and Matsuzoe et al. (1998) who reported that lycopene was increased under water stress than under well watered conditions.

The increase in lycopene content of tomato fruit under water stress conditions could interpreted on the base that plants growing under stress conditions react by increasing their antioxidant production from both nonenzymatic systems which including lycopene (Apel and Hirt, 2004). Moreover, as it is well known that abscisic acid (ABA) is a primary stress indicator for drought pathways in plants to increase the plants response to desiccation. The lycopene and B- carotene accumulation in the fruits were accompanied by an increase of ABA content (Chaves et al., 2009). Ethylene which also largely accumulates in stressed plant as like ABA, also increases carotenoids concentration in tomato fruits (Basiouny et al., 1994 and Paz et al., 1982).

Data in Table 5 show that using any of the three adaptable treatments reduced lycopene content in tomato fruits compared to those of untreated control. This result seems to be accepted as such treatments reduce the deleterious effect of drought and hence reduce the synthesis of secondary metabolites as well as antioxidants, therefor lycopene decreased. Using drought pretreatment as an adapting method enhanced lycopene content in tomato fruits than those obtained by using other two treatments (antitranspirant and mycorrizal) in both seasons but the increment in lycopene content as result of using the former treatment was significant only in the 2015 season. Results obtained in Table 5 also show that the highest and lowest values of lycopene contents were in fruits produced from control plants when 
combined with the lowest and highest amount of irrigation water respectively.

\section{REFERENCES}

Abbate, P.E., J. L. Dardanelli, M. G. Cantarero, M. Maturano, R.J.M. Melchiori and E. E. Suero (2004). Climatic and water availability effects on water-use efficiency in wheat. Crop Sci. 44:474-483.

Abdel- Razik, A.M. (2012). Effect of different irrigation regimes on quality and storability of Mango fruits. J. Hort. Sci. \& ornamental plants. 4(3): 247252.

Abou - khaled, A., R.M. Hagan and D.C. Devenport (1970). Effects of kaolinite as a reflective antitranspirants on leaf temperature, transpiration, photosynthesis and water use efficiency. Water Resources.Res. 6: 280 - 289.

Agbemafle, R., J. Owusu- Sekyere, A. Bart-Plange and J. Otchere (2014). Effect of deficit irrigation and storage on physiochemical quality of tomato variety "Pechtomech". Food Sci. \& quality management. 34: 113- 119.

Al-Karaki, G.N. (1998). Benefit, cost and water-use efficiency of arbuscular mycorrhizal durum wheat grown under drought stress. Mycorrhiza. 8:41-45.

Al-Karaki, G.N. and R. B. Clark (1999). Varied rates of mycorrhiza inoculums on growth and nutrient acquisition by barley grown with drought stress. J. Plant Nut. 22:1775-1784.

A.O.A.C. (1965). Official Methods of Analysis of the Association of Official Analytical Chemists. published by the A.O.AC. International10 ${ }^{\text {th }}$ ed. Washington, D. C.

A.O.A.C. (1975). Official Methods of Analysis of the Association of Official Analytical Chemists. published by the
A.O.AC. International $12^{\text {th }}$ ed. Washington, D. C.

A.O.A.C. (2003). Official Methods of Analysis of the Association of Official Analytical Chemists. published by the A.O.AC. International18thEd. Washington, D. C.

Apel, K. and H. Hirt (2004). Reactive oxygen spices: Metabolism, oxidative stress and signal transduction. Ann. Rev. Plant Biol. 55: 373- 399.

Aron, I. (1972). Crop production in dry regions Vol. (2): background and principles. London: Leonard Hill (Plant Science Monographs).

Auge, R. M., A. Kurt, Schekel and R.L. Wample (1987). Rose leaf elasticity changes in response to mycorrhizal colonization and drought acclimation. Physiol. Plant. 70:175-182.

Auge, R.M. (2001). Water relation, drought and vesicular-arbuscular mycorrhizal symbiosis. Mycorrhiza. 11: 3-42.

Aurand, R., M. Faurobert, D. Page, J.F. Maingonnat, B. Brunel, M. Causse and N. Bertin (2012). Anatomical and biochemical trait network underlying genetic variations in tomato fruit texture. Eyphytica. 187: 99- 119.

Barrs, H. D. and P. E. Weatherly (1962). A re-examination of the relative turgidity technique for estimating water deficit in leaves. Aust. J. Biol. sci. 15: 413428.

Basiouny, F.M., K. Basiouny and M. Maloney (1994). Influence of water stress on the abscisic and ethylene production in tomato under different PAR levels. J. Hort. Sci. 69(3): 535-541.

Beverly, R.B. and J.G. Latimer (1995). Drought and mechanic conditioning of tomato and eggplant transplants have little effect on subsequent yield. Proceedings of the Florida State. Hort. Society.107: 109-111.( C.F. Hort. Abstr. Vol. 66: 5089). 
Boyer, J. S. (1969). Measurements of the water status of plant. Ann. Rev. Plant Physiol. 20: 351-364.

Brown, G.B. (1955). The ascorbic acid content of tomatoes as related to illumination. J. Am. Soc. Hort. Sci. 65: 3185- 3188.

Cayuela, E., A. Munoz-Mayor, F. VicenteAgullo, E. Moyano, J.O. Garica Abellan, M.T. Estan and M.C. Bolarin (2007). Drought pretreatment increases the salinity resistance of tomato plants. J. Plant. Nut. Soil Sci. 170 (4): 479- 484.

Chaves, M.M., J. Flexas and Pinheiro, C. (2009). Photosynthesis under drought and salt stress: regulation mechanisms from whole plant to cell. Ann. Bot. 103: 551- 560.

Chen, J., S. Kang, T. Du, R. Qiu, P. Gue and R. Chen (2013). Quantative response of greenhouse tomato yield and quality to water deficit at different growth stages. Agric. Water Management, 129: 152- 162.

Chengkun, H. E., G. Suzhi and Li. Jiashen (1996). Effects of drought stress on activated oxygen metabolism in tomato. J. of fujian agric. univ. 25(3) p:307- 311. (C.F. Hort. Abstr.Vol.67: 7009).

Courtecuisse, R. (1999). Mushrooms of Britain and Europe, Collins and the Wildlife Trusts.

Cuartero, J., M. S. Bolarin, M. J. Asins and V. Moreno (2006). Increasing salt tolerance in the tomato. J. Exper. Bot. 57 (5): 10451058.

Duan, X., D.S. Neuman, J.M. Reiber, C.D. Green, A.M. Saxton and R.M. Augé (1996). Mycorrhizal influence on hydraulic and hormonal factors implicated in the control of stomatal conductance during drought. J. Exp. Bot. 47:1541-1550.

Edathil, T.T., S. Manian and K. Udaiyan (1996). Interaction of multiple VAM fungal species on root colonization plant growth and nutrient status of tomato seedlings. (lycopersicon esculentum Mill). Agric. Ecosystems \&Environ 59: 63-68. (C.F. Hort. Abstr 67(4): 3182).

Farahani, A., H. Lebaschi, M. Hussein, S. A. Hussein, V. A. Reza and D. Jahanfar (2008). Effects of arbuscular mycorrhizal fungi, different levels of phosphorus and drought stress on water use efficiency, relative water content and proline accumulationrate of Coriander (Coriandrum sativum L.). J. of Medic. Plants Res. 2(6): 125- 131.

Farooq, M., S.M.A. Basra, A. Wahid, N. Ahmad and B.A. Saleem (2009a). Improving the drought tolerance in rice (Oryza sativa $L$.) by exogenous application of salicylic acid. J. Agron \& Crop Sci. 195: 237- 246.

Farouk, S. and Amany A. Ramadan (2012). Improving growth and yield of cowpea by foliar application of chitosan under water stress. Egypt. J. of Biol. (14) pp: 14-26.

Giannakoula, Anastasia, E. and I. F. Ilias. (2013). the effect of water stress and salinity on growth and physiology of tomato (Lycopersicon esculentum Mill). Arch. Biol. Sci., Belgrade. 65 (2): 611-620.

Gonzalez- Fernandez, J. J. (1996). Tolerancia a la salinided en el tomato en estado de plantula en planta adulta. Tesis doctoral. Cordoba Uni. Spain. In (Cuartero, J., Bolarin M. S., Asins, M. J. and Moreno, V.(2006). Increasing salt tolerance in the tomato. J. of Exper. Bot. 57 (5):1045-1058).

Ho, L. and P. Grimbly (1990). The physiological basis for tomato quality. Grower 113(8): 33-36.

Hobson, G. and D. Grierson (1993). Tomato. In: G Seymour, J Taylor, G Tucker. eds. Biochem. fruit Ripening. 
London UK, Chapman and Hall, pp.405- 442.

Ingram, J. and D. Bartels (1996). Molecular basis of dehydration tolerance. Annu. Rev. Plant Physiol. Plant Mol. Biol.47: 377- 403.

Ito, O. and S. Kuawai (1994). Effect of watering control on the fruit qualities of tomato and cherry tomato. Research Bulletin of the Aichi-ken Agric. Research Center. 26: 191- 199. (C.F Hort. Abstr. Vol. 66:3267).

Kaya, C., D. Higgs, H. Kirnak and I. Tas (2003). Mycorrhizal colonisation improves fruit yield and water use efficiency in water- melon (Citrullus lanatus Thunb) grown under wellwatered and water-stressed conditions. Plant \& Soil. 253:287-292.

Kiani, S.P., P. Talia, P. Maury, P. Grieu, R. Heinz, A. Perrault, V. Nishinakamasu, E. Hopp, L. Gentzbittel, N. Paniego and A. Sarrafi (2007). Genetic analysis of plant water status and osmotic adjustment in recombinant inbred lines of sunflower under two water treatments. Plant Sci. 172:773-787.

Kirkham, M.B. (2005). Principles of soil and plant water relations. Dona Drebelbis, Elsevier Academic Press publications, Pp: 519.

Klunklin, W. and G. Savage (2017). Effect on quality characteristics of tomatoes grown under well- watered and drought stress conditions. Foods. 6 (56): 1-10.

Krinka, H., C. Kaya, I. Tas and D. Higgs (2001). The influence of water deficit on vegetative growth, physiology, fruit yield and quality in egg plants. Bulg. J. Plant Physiol. 27(3-4): 34-46.

Liptay, A., A.P. Papadopoulos, H.H. Bryan and O. Cull (1986). Ascorbic acid levels in tomato at low temperature. Agric. Biol. Chem. 50(12): 3185- 3187.

Liu, H., A.W. Duan, J.S. Sun and Y.Y. Liang (2009). Effects of soil moisture regime on greenhouse tomato yield and its formation under drip irrigation. Ying Yong Sheng Tai Xue Bao. 20(11): 2699-2704.

Liu, M.C. and D.K. Chen (2002). Effect of deficit irrigation on yield and quality of cherry tomato. China Vegetables 6, 46 (in Chinese).In(Chen, J., Kang, S., Du, T., Qiu, R., Guo, P. and Chen,R.(2013). Quantitative response of greenhouse tomato yield and quality to water deficit at different growth stages. Agri. Water Management 129: 152- 162.)

Lopez, A., K. Zon, M.C. Dussi, P. Reed, G. Giardina, M. Leokovar and L. Flores (2011). Economic evaluation between chemical thinning vs. hand thinning in "Williams" pear. In : Sanchez Leuven, Belgium: International Society for Horticultural Science 29: 240-245.

Malash, N. M. and Ragaa A. R. Gawish (1990). Effect of growth regulator and antitranspirant on salt tolerance in Cowpea. Menufia J. Agric. Res. Vol. 15 (1) :845- 876.

Malash, N. M. and Entesar A. Khattab (2008). Enhancing salt tolerance in adult tomato plants by drought pretreatment applied at the seedling stage. Emirates J. of Food and Agric. 20(1): 84-88.

Matsuzoe, N., K. Zushi and T. Johjima (1998). Effect of soil water deficit on coloring and carotene formation in fruits red, pink, and yellow type cherry tomatoes. J. of the Japanese Society for Hort. Sci. Vol. 67(4):600-606.

(C.F. Hort. Abstr. Vol. 68: 9671).

McCollum, J.P. (1944). Some factors affecting the ascorbic acid content of tomatoes. Proc. Amer. Soc. Hort. Sci. : 382- 386.

Mitchell, J.P. and C. Shennan (1991). Tomato fruit yields and quality under water deficit and salinity. J. AMER. SOC. HORT. SCI. 116 (2): 215-221. 
Mitchell, J.P., C. Shennan, S.R. Grattan and D.M. May (1991). Tomato fruit, yield and quality under water deficit and salinity. J. Amer. Soc. Hort. Sci. 116(2): 215-221.

Moftah, A.E and A.I. Al-Humaid (2005). Effects of Kaolin and Pinolene Filmforming polymers on water relations and photosynthetic rate of Tuberose (Polianthes tuberosa L.). J. of King Saudi Univ. Vol (18) Agric. Sci.(1): 3549.

Nahar, K. and R. Gretzmacher (2002). Effect of water stress on nutrient uptake, yield and quality of tomato (Lycopersicon esculentum Mill.) under subtropical conditions. Die Bodenkultur. 53(1):45- 51.

Nahar, K and S. M. Ullah (2011). Effect of water stress on moisture content distribution in soil morphological characters on two tomato cultivars.J. Sci. Res., 3(3): 677- 682.

Nuruddin, M. M., C.A. Madramootoo and G.T. Dodds (2003). Effects of water stress at different growth stages on greenhouse tomato yield and quality. Hort. Sci. 38: 1389- 1393.

Ozkur, O., F. Ozdemir, M. Bor and I. Turkan (2009). Physiochemical and antioxidant responses of the perennial xerophyte Capparis ovate Desf. to drought. Environ. Exp. Bot. 66:487492.

Panagiotopoulos, L.J. and R. Fordham (1995). Effect of water stress and potassium fertilisation on yield and quality (flavour) of table tomatoes (lycopersicon esculentum Mill). Acta. Hort. (379):131-120 (C.F.Hort. Abstr. Vol. 66 :502).

Patil, B.B. and R. De (1976). Influence of nitrogen fertilization and antitranspirants on the economics of production of dry land rapeseed. Indian J. Agric. Sci.46 : 21-25.
Paz, O., H. W. Janes, B.A. Prevost and C. Frenkel (1982). Enhancement of fruit sensory quality by post- harvest applications of acetaldehyde and ethanol. J. Food Sci. 47 (1): 270-273.

Pulupol, L.U., M.H. Hossein Behboudian and K.J. Fisher (1996). Growth, yield and postharvest attributes of glasshouse tomatoes produced under deficit irrigation. Hort. Sci. 31: 926929.

Rahman, S.M.L., E. Nawata and T. Sakuratani (1998). Evaluation of drought tolerance of tomato cultivars. Japanese. J. of Tropical Agric. 42(1): 9-38(C.F. Hort. Abstr. Vol. 68:10576).

Rao, D.V.R. and S.S.V. Padma (1991). Effect of induced moisture stress at different phenological stages on growth and yield tomato cultivars. South Indian Hort. vol 39(2): 8187(C.F. Hort. Abstr. Vol. 65: 5461).

Roa, N.K.S. and R.M. Bhatt (1992). Responses of tomato to moisture stress: plant water balance and yield. Plant Physiol. Biochem. New Delhi. 19(1): 36-41.

Ruiz-Lozano, J.M. (2003). Arbuscular mycorrhizal symbiosis and alleviation of osmotic stress. New perspectives for molecular studies. Mycorrhiza. 13: 309 -317.

Sairam, R.K. and G.C. Srivastava (2001). Water stress tolerance of wheat (Triticum aestivum $L$ ) variations in hydrogen peroxide accumulation andantioxidant activity in tolerant and susceptible genotypes. J. Agron. Crop \&Sci. 186: 63- 70.

Samuel, K. and K. Paliwal (1994). Effect of water stress on water relations, photosynthesis, and element content of tomato. Plant Physiol. \& Biochem.21 (1):33-37.(C.F Hort. Abstr. vol. 66: 9603).

Selosse, M.A., F. Richard, X. He and S.W. Simard (2006). "Mycorrhizal networks: 
des liaisons dangereuses?". Trend Ecology Evolution. 21(11): 621-628.

Sivakumar, R. and S. Srividhya (2016). Impact of drought on flowering, yield and quality parameters in deverse genotypes of tomato (Solanum lycopersicum L.). Adv. Hort. Sci. 30(1): 3-11.

Smith, Sally. E., I. Jakobsen, M. Gronlund and A.F. Smith (2011). Roles of arbuscular mycorrhizas in plant phosphorus nutrition: interactions between pathways of phosphorus uptake in arbuscular mycorrhizal roots have important implications for understanding and manipulating plant phosphorus acquisition. American Society Plant Biologists. Vol. 156, pp. 1050-1057.

Snedecor, G.W. and W.G. Cochran (1980). Statistical Methods. 7th Ed. Ames: lowa State university press.

Subramanian, K.S., C. Charest, L.M. Dwyer and R.I. Hamilton (1995). Arbuscular mycorrhizas and water relations in maize under drought stress at tasselling. New Phytologist. 129:643-650.

Subramanian, K.S., P. Santhanakrishnan and P. Balasubramanian (2006). Responses of field grown tomato plants to arbuscular mycorrhizal fungal colonization under varying intensities of drought stress. Scientia Horticulturae. 107:245-253.

Subramanian, K.S., P. Santhanakrishnan and P. Balasubramanian (2006). Responses of field grown tomato plants to arbuscular mycorrhizal fungal colonization under varying intensities of drought stress. Scientia Horticulturae. 107:245-253.

Taiz, L. and E. Zeiger (2010). Plant Physiology, $5^{\text {th }}$ ed. Sinauer Associates Inc. Publishers, Massachusetts.

Toor, R.K., G.P. Savage and A. Heeb (2006). Influence of different types of fertilizers on the major antioxidant components of tomatoes.J. of Food Composition and Analysis 19(1): 2027.

UI, M. A., F. Dorsan and I.H. Tuzel (1994). Effect of different irrigation intervals and levels on yield of processing tomatoes.Ege Universitesi Ziraat Fakultesi Dergisi 31(2/3):1-8. (C. F. Hort. Abstr. Vol. 65: 9826).

Veit- kohler, U., A. Krumbein and $H$. Kosegarten (1999). Effect of different water supply on plant growth and fruit quality of Lycopersicum esculentum. J. Plant Nut. Soil Sci. 162: 583-588.

Vieira, R.D., D.M. Tekrony and D.B. Egli (1991). Effect of drought and defoliation stressed in the field on soybean seed germination and vigour. Crop Sci. 32(2): 471-475.

Villar-Salvador, P., R. Planelles, I. Oliet, J. L. Peñuelas-Rubira, D.F. Jacobs and M. González (2004). Drought tolerance and transplanting performance of holm oak (Quercus ilex) seedlings after drought hardening in the nursery. Tree Physiol. 24: 1147-1155.

Yin, Y.G., Y. Kobayashi, A. Sanuki, S. Kondo, N. Fukuda and C. Matsukara (2010). Salinity induces carbohydrate accumulation and sugar- regulated starch biosynthetic genes in tomato fruits in an ABA- and osmotic stressindependent manner. J. Exp. Bot. 61: 563- 574.

Yoon, J.Y., S.K. Green, Tschanz, Tsou, S.C.S. and L.C. Chang (1989). Pepper improvement for the tropics: problems and the AVRDC approach. Tomato and pepper production in the tropics Proceedings of the International Symposium on Integrated Management Practices: 86-98, Tainan, Taiwan, 21-26 March 1988.

Zhao, T. J., S. Sun, Y. Liu, J.M. Liu, Q. Liu, Y.B. Yan and H.M. Zhou (2006). Regulating the drought- responsive element (DRE)-mediated signaling pathway by synergic functions of trans-active and transinactive DRE binding factors in Brassica napus. J. Biol.Chem. 281:10752-10759. 
تحفيز المقاومة للجفاف فى نباتات الطماطم النامية تحت ظروف نظم رى مختلفة باستخدام بعض المعاملات الزراعية

نبيل محمد ملش ، محمد عبدالفتاح فتح الله ، منى رشدى خليل ، إيمان سعيد عبدالعال

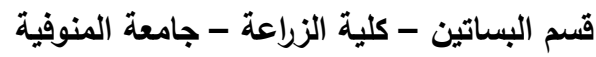

الملخص العربى

تعتبر الطماطم من أهم محاصيل الخضر من حيث قيمتها الاقتصادية والغذائية فى مصر وفى العالم. نقص المياه هى إحدى المشاكل الرئيسية وإلمنتشرة فى المناطق الجافة وشبه الجافة فى العالم كما هى فى منطقة البحر المتوسط إما نتيجة

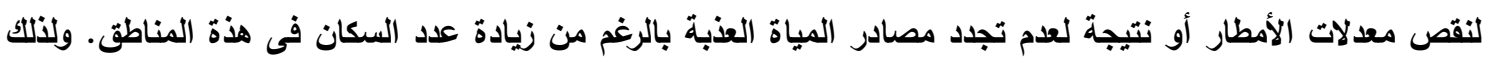
هناك جهود تبذل وتجارب تجرى من أجل تحسين أقلمة المحاصيل النباتية ويالذات الإقتصادية منها لزيادة مقاومتها وتحملها لنقص مياة الرى. ففى هذة الداسة رويت نباتات الطماطم صنف "اليسا" بثلاث كميات مختلفة من المياة وهى

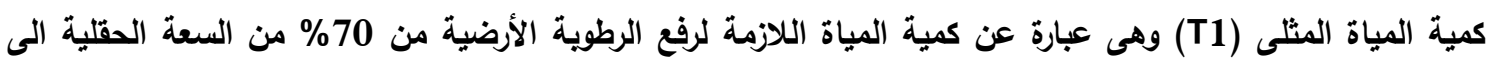

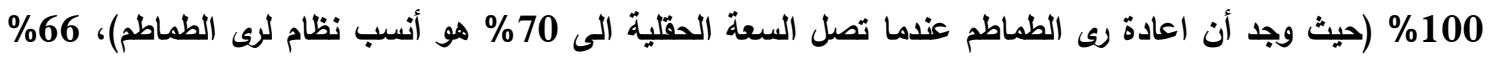
(T3)\%33 من كمية المياه المثلى، بالاضافة الى ذلك عوملت نباتات الطماطم بثلاث معاملات لرفع درجة

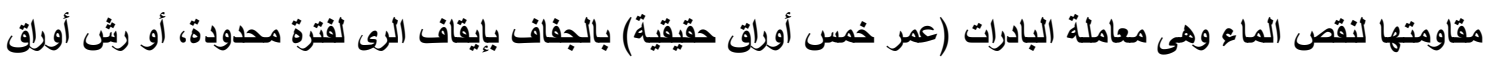

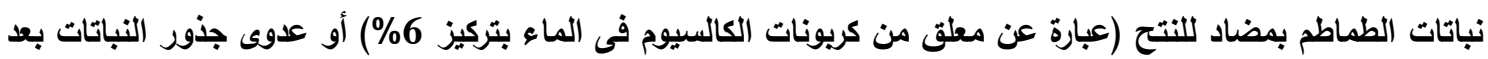
شتلها بفطر الميكوريزا علاوة على نباتات الكنترول التى لم تعامل.

وتثبير النتائج على أن نقص مياة الرى المضافة أدى الى نقص تدريجى ومعنوى فى المحتوى النسبى للماء

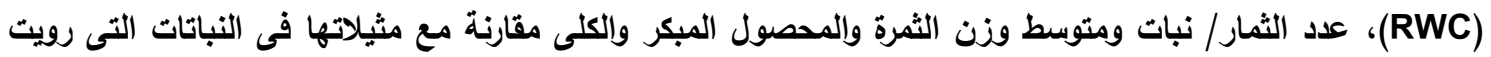
بكمية المياة المثلى(T1 ). ويعود النقص فى المحصول الكلى الى النقص فى كل من عدد الثمار ومتوسط وزن الثمرة. وعلى العكس من ذلك فقد أدت معاملات نقص الماء(T2\&T3) الى زيادة كفاءة استخلام الماء علاوة على تحسين صفات الجودة من حيث زيادة كل من فيتامين C، المواد الصلبة الذائبة الكلية (TSS)، الحموضة المعايرة وصلابة الثمار وكنلك لكاده تحسين اللون (زيادة صبغة الليكويين) فى الثمار الناضجة. وقد عللت تحسين صفات الجودة فى الثمار باستعمال كميات أقل من المياة الى أن النباتات تحت ظروف نقص المياة تلجأ الى تغيير مسار العمليات الغذائية بحيث تكون مركبات ثانوية فئه بارجة أكبر كوسيلة للافاع، ومن هذة المركبات السكريات، الأحماض العضوية، الفيتامينات، والكاروتينويدات ........الخ. جدير بالذكر أن معاملات زيادة مقاومة النباتات لنص المياة الثلاثة (الرش بمثبط النتح، معاملة البادرات بالجفاف والعدوى بالميكوريزا ) فى معظم الحالات أدت الى تخفيف أضرار نقص الماء على نباتات الطماطم حيث أنها حسنت معنويا المحصول ومكوناته للنباتات عن تلك التى لم تعامل (نباتات الكنترول) وذلك تحت ظروف كل من الته الرى بالكمية المناسبة

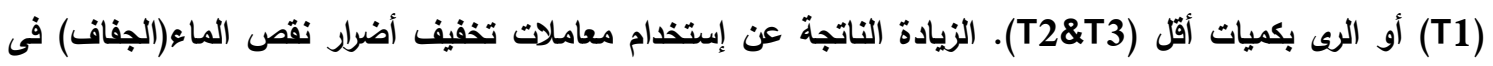
المحصول ترجع أساسا الى الزيادة فى متوسط وزن الثمرة ولكن بلرجة أقل الى عدد الثمار. بالاضافة الى ذلك أدت هذة الثة 
المعاملات (معاملات زيادة مقاومة الجفاف) الى تحسين الحالة المائية للنباتات (RWC) وزيادة كفاءة استخدام المياة

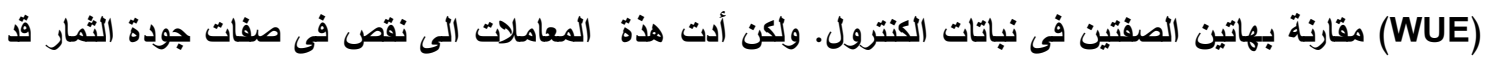

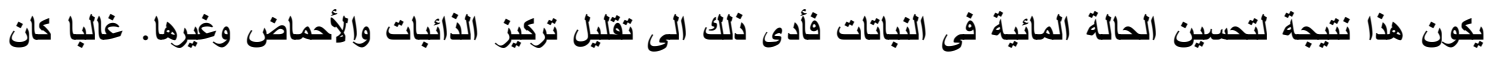
أعلى القيم المتحصل عليها فى المحصول ومكوناته ترجع الى إستخدام مثبط النتح خاصة عندما تروى النباتات بالكمية

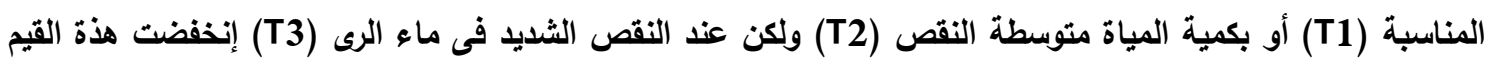

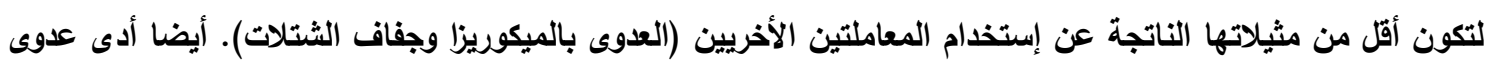

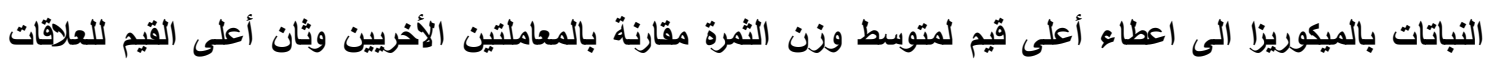

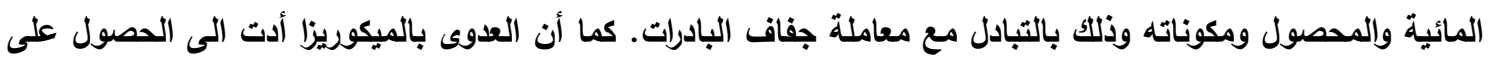
أعلى قيم لصفات المحصول ومكوناته عندما رويت بأقل كمية من المياة (T3 ) مقارنة بقيم المعاملتين الأخريين.

$$
\begin{aligned}
& \text { أسماء السادة المحكمين } \\
& \text { أ.د/ فتوح أبواليزيد علـــى ق قسم البساتين - كلية الزراعة- المنوفية }
\end{aligned}
$$

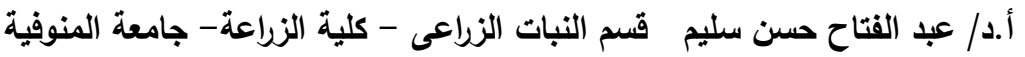


N.M. Malash, et al., 